\title{
Myristica fragrans Shells as Potential Low Cost Bio-Adsorbent for the Efficient Removal of Rose Bengal from Aqueous Solution: Characteristic and Kinetic Study
}

\author{
Azal Shakir Waheeb ${ }^{1}$, Hassan Abbas Habeeb Alshamsi², \\ Mohammed Kassim Al-Hussainawy ${ }^{3}$, and Haider Radhi Saud ${ }^{1{ }^{1 *}}$ \\ ${ }^{1}$ Department of Chemistry, College of Science, University of Al-Muthanna, Al-Samawa, Iraq \\ ${ }^{2}$ Department of Chemistry, College of Education, University of Al-Qadisiyah, Diwaniya, Iraq \\ ${ }^{3}$ Directorate of Al Muthanna Education, Al-Samawa, Iraq
}

*Corresponding author:

tel: $+964-7822505228$

email: hiader.radee@gmail.com

Received: October 2, 2019

Accepted: December 16, 2019

DOI: $10.22146 /$ ijc. 50330

\begin{abstract}
In the present study, the Myristica fragrans shells (MFS) was used as low-cost bio adsorbent for the removal of Rose Bengal (RB) dye from aqueous solutions. The characteristics of MFS powder were studied before and after adsorption using different techniques such as Fourier transform Infrared spectroscopy (FTIR), Thermal Gravimetric Analysis (TGA), BET and BJH surface area analysis, Atomic Force Microscopy (AFM) and Scanning Electron Microscopy (SEM). Batch adsorption was adopted to evaluate the effect of various parameters on the removal of $R B$ such as; time of contact (5-75 $\mathrm{min})$, initial dye concentration (10-50 $\left.\mathrm{mg} \mathrm{L}^{-1}\right)$, adsorbent dose $\left(0.1-1.7 \mathrm{~g} \mathrm{~L}^{-1}\right)$ and $\mathrm{pH}(3-12)$. The results revealed that the coverage of MFS surface by $R B$ molecules involved the formation of ester bond (esterification), and the pore diameter decreased from 190.55 to $2.43 \mathrm{~nm}$ when adsorption of RB onto MFS surface occurred. Experimental adsorption data were modelled using isotherm models including Langmuir, Freundlich, and Temkin. Temkin isotherm demonstrated to be the best isothermal model, and the results indicate that the adsorption of Rose Bengal on MFS surface follows pseudo second-order kinetics model. The adsorption of dye at different $\mathrm{pH}$ media showed that the esterification process was more preferred in acidic solution.
\end{abstract}

Keywords: Myristica fragrans; chemical adsorption; Rose Bengal; isotherms; FESEM; $B E T$

\section{- INTRODUCTION}

The spread of huge quantities of toxic contaminants in surface water and groundwater has a potential effect on human health [1]. There are numerous toxic contaminants found in wastewater such as, heavy metals, Radiological contaminants, synthetic organic and inorganic contaminants (i.e., dyes, pesticides, phenolic compounds, petrochemicals, pharmaceuticals, etc.) [2-5]. Water contaminated with untreated dyes can cause a serious environmental impendence to aquatic and human life [6]. Many type of dyes are non-biodegradable in nature and under anaerobic conditions might decompose into carcinogenic aromatic amines [7]. Rose Bengal dye is a fluorescent compound that is widely used in early-stage diagnosis of keratoconjunctivitis sicca (KCS) in vivo effect on the human corneal epithelium [8]. Xanthene dyes have toxicity which cause a series of risks on the human health especially by inhibition of human drugmetabolizing enzymes and can cause eye redness and itching [9].

Among waste water treatments such as, ozonation, photochemical degradation, reverse osmosis, membrane separation and coagulation, the adsorption process is the most effective, low cost and most easily available method that has been successfully employed for removing pollutants from the waste water [10]. Kaur et al. used UV light for the degradation of dyes and found that under UV light, very small degradation was observed [11]. 
Numerous studies have focused on the utilization of natural materials, such as egg shells [12], bean peels [13], and marble waste [14], as adsorbents for the removal of pollutants from aqueous mediums. Activated carbon is the most widely used adsorbent for the removal of dyes from waste water effluents, due to its high capacity for organic compounds, howeverits application is still limited due to the high cost [15].

Myristica fragrans shell (MFS) is a waste product of the nutmeg industry. In the present study, MFS have been utilized for the removal of toxic materials from water. The adsorption dye on MFS surface was evaluated using different variable parameters. In addition, techniques such as AFM, FESEM, FTIR, BET/BJH, and TGA/DTA were used to elucidate the effect of dye adsorption on the surface characteristics of the adsorbent.

\section{- EXPERIMENTAL SECTION}

\section{Materials}

Hydrochloric acid ( $\mathrm{HCl}, 37 \%)$, and Sodium hydroxide $(\mathrm{NaOH}, 99.5 \%)$ were purchased from $\mathrm{BDH}$. Rose Bengal $\left(\mathrm{C}_{20} \mathrm{H}_{2} \mathrm{Na}_{2} \mathrm{O}_{5} \mathrm{I}_{4} \mathrm{Cl}_{4}\right.$, Dye content $\left.95 \%\right)$ was purchased from Sigma-Aldrich. The chemical structure of $\mathrm{RB}$ dye is present in Fig. 1. It is well-known that RB possess high solubility in water, and its $\lambda \max =549 \mathrm{~nm}$.

\section{Procedure}

\section{Preparation of adsorbent}

The MFS powder was obtained from MFS waste, and was ground and sieved through 150 mesh sieve. After sieving, the collected fine powder was washed several times with distilled water to remove contaminants and soluble materials. The clean powder was then dried in an oven at<smiles>Cc1c2oc3c(C)c(O[N+](=O)[O-])c(I)cc3c(-c3c(Cl)c(Cl)c(Cl)c(Cl)c3C(=O)O)c-2cc(I)c1=O</smiles>

Fig 1. Rose Bengal chemical structure
$100{ }^{\circ} \mathrm{C}$ for $4 \mathrm{~h}$ and it was placed in a desiccator to keep dry until use.

\section{Batch mode adsorption studies}

The adsorption studies were done by batch experiments which aimed to determine the adsorption parameters such as contact time initial dye concentration, initial $\mathrm{pH}$ solution, and adsorbent dose by changing one parameter under study, while other parameters were set in a fixed value. Different concentrations $(10,20,30$, and $40 \mathrm{ppm})$ were obtained by successive dilution of a dye stock solution of $50 \mathrm{ppm}$. Five conical flasks $(250 \mathrm{~mL})$ containing $100 \mathrm{~mL}$ of dye solution and $1.7 \mathrm{~g}$ of MFS surface were stirred on a shaker water bath at the rate of $120 \mathrm{rpm}$ for the required time of equilibrium. The equilibrium concentration of the solution were determined by using UV-Visible technique (Shimadzu, UV-1650PC) at $\lambda$ max (nm), after separation of the supernatant. The quantity and the removal percentage of the adsorbed dye on the adsorbent at the equilibrium time $\left(\mathrm{q}_{\mathrm{e}}\right)$ were calculated using Eq. (1) and (2) respectively.

$\mathrm{q}_{\mathrm{e}}=\frac{\mathrm{V}\left(\mathrm{C}_{0}-\mathrm{C}_{\mathrm{e}}\right)}{\mathrm{m}}$

$\mathrm{q}_{\mathrm{e}}=\frac{\mathrm{V}\left(\mathrm{C}_{0}-\mathrm{C}_{\mathrm{e}}\right)}{\mathrm{m}}$

where $\mathrm{C}_{0}$ and $\mathrm{C}_{\mathrm{e}}$ are $\mathrm{RB}$ concentrations (ppm) at the initial and the equilibrium time, respectively. $\mathrm{q}_{\mathrm{e}}\left(\mathrm{mg} \mathrm{g}^{-1}\right)$, is the amount of RB adsorbed on a fixed adsorbent mass (g) at the time of equilibrium. V is the volume (in L) of the initial RB solution.

\section{Characterization}

MFS before and after dye adsorption were characterized by Shimadzu 8400S FTIR with wavenumber range of $400-4000 \mathrm{~cm}^{-1}$ at a scan resolution of $4 \mathrm{~cm}^{-1}$. Field emission scanning electron microscope (FESEM, MIRA3 TESCAN) with accelerating voltage $10 \mathrm{kV}$ and angstrom AFM (SPMAA3000) were used to study the surface morphology of MFS surface. Under nitrogen atmosphere at $20 \mathrm{~mL} / \mathrm{min}$ gas flow rate and heating at the rate of $20 \mathrm{~min}^{-1}$, the thermogravimetric analysis (TGA) was done by Perkin Elmer (TGA 4000). Surface area and pore analysis were carried out using Nova 
2000e, (Quantachrome, Instruments Limited, USA) and the methods of the multipoint Brunauer, Emmett, and Teller (BET) method and BJH method.

\section{- RESULTS AND DISCUSSION}

\section{Characterization of MFS Before and After Adsorption}

\section{Functional groups}

The FTIR spectrum of MFS before and after dye adsorption are shown in Fig. 2, in which the MFS spectrum shows a broad peak centered at $3385 \mathrm{~cm}^{-1}$ due to the intramolecular and intermolecular hydrogen bonding of the $-\mathrm{OH},-\mathrm{NH}_{2}$ groups. Stretching and bending vibration of the C-H band is shown in the MFS FTIR spectrum at 2930, 2884, 1427, 1381, and $1321 \mathrm{~cm}^{-1}$. A strong peak located at $1653 \mathrm{~cm}^{-1}$ is indexed to the carbonyl group $(\mathrm{C}=\mathrm{O})$ stretching vibration, while a weak band with multiple peaks at $1040,1123,1238$ and $1267 \mathrm{~cm}^{-1}$ is assigned to alcohols, carboxylic acids and ethers (1000-
$1320 \mathrm{~cm}^{-1}$ attributed to $\mathrm{C}-\mathrm{O}$ stretch) [16]. As reported in the literatures, the carbonyl stretching vibration of free RB is shown at $1614 \mathrm{~cm}^{-1}$ [17]. The FT-IR spectra of MFS after dye adsorption shows the carbonyl frequency at wavenumber, $1734 \mathrm{~cm}^{-1}$, which confirms that the dye has been covalently attached to the MFS, and also the formation of an ester bond between alcoholic and carboxylic groups [18]. In addition, a broadband of $3385 \mathrm{~cm}^{-1}$ was shifted to higher wavenumber of $3419 \mathrm{~cm}^{-1}$ due to the weakness of the MFS intermolecular hydrogen bonding between its molecules after adsorption of the RB dye.

\section{Surface topology}

AFM image of the MFS before adsorption is depicted in Fig. 3(a). As AFM technique reveals, the morphology of MFS to be a porous surface with roughness average of about $5.35 \mathrm{~nm}$ and surface skewness of about -0.234. Fig. 3(b) depicts the AFM images of the

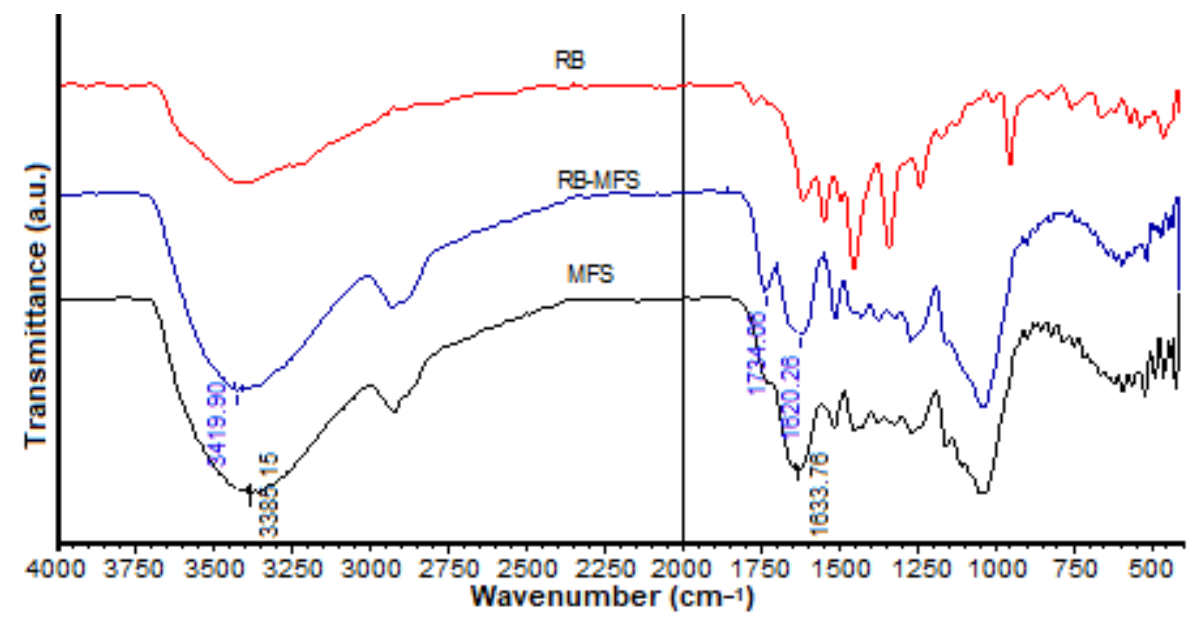

Fig 2. FTIR spectra of RB dye and MFS before and after dye adsorption
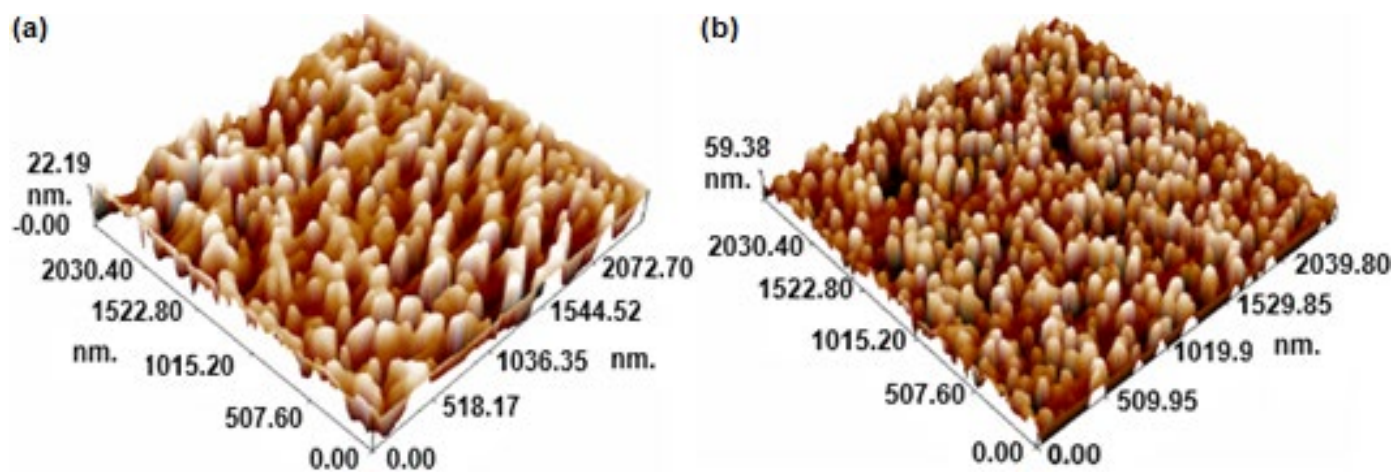

Fig 3. AFM images of MFS (a) before) and (b) after dye adsorption 
MFS after adsorption of the dye. Dye adsorption causes the lowering of porosity of the MFS surface and increasing of thickness in comparison with the state before adsorption. The AFM rough analysis of the MFS negative Skewness is due to the number of surface valleys that were higher than the peaks [19], and after adsorption of the dye, the skewness value became positive due to the decrease in the number of valleys and enclosed by dye molecules [20].

\section{Surface morphology}

The surface morphology of MFS before and after adsorption were examined by scanning electron microscopy, as presented in Fig. 4. MFS image shows irregular particle shapes with large scale of pores. After dye adsorption, the surface of MFS was smooth and had no sharp edges with small scale pores in compression with MFS, and the coated surface clearly shows that dye particles were accumulated on the surface of MFS.

\section{Surface area and porosity}

Fig. 5 shows BET adsorption-desorption isotherms of MFS before and after adsorption. The obtained surface properties such as the BET surface area, and the BJH pore volumes are summarized in Table 1 . According to
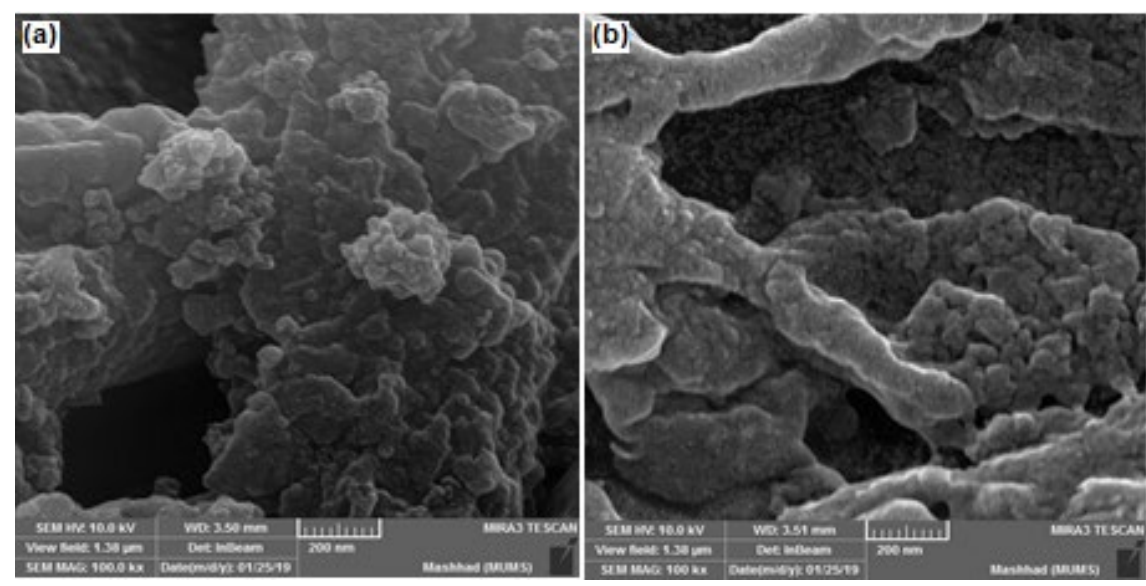

Fig 4. SEM images of MFS (a) before and, (b) after dye adsorption
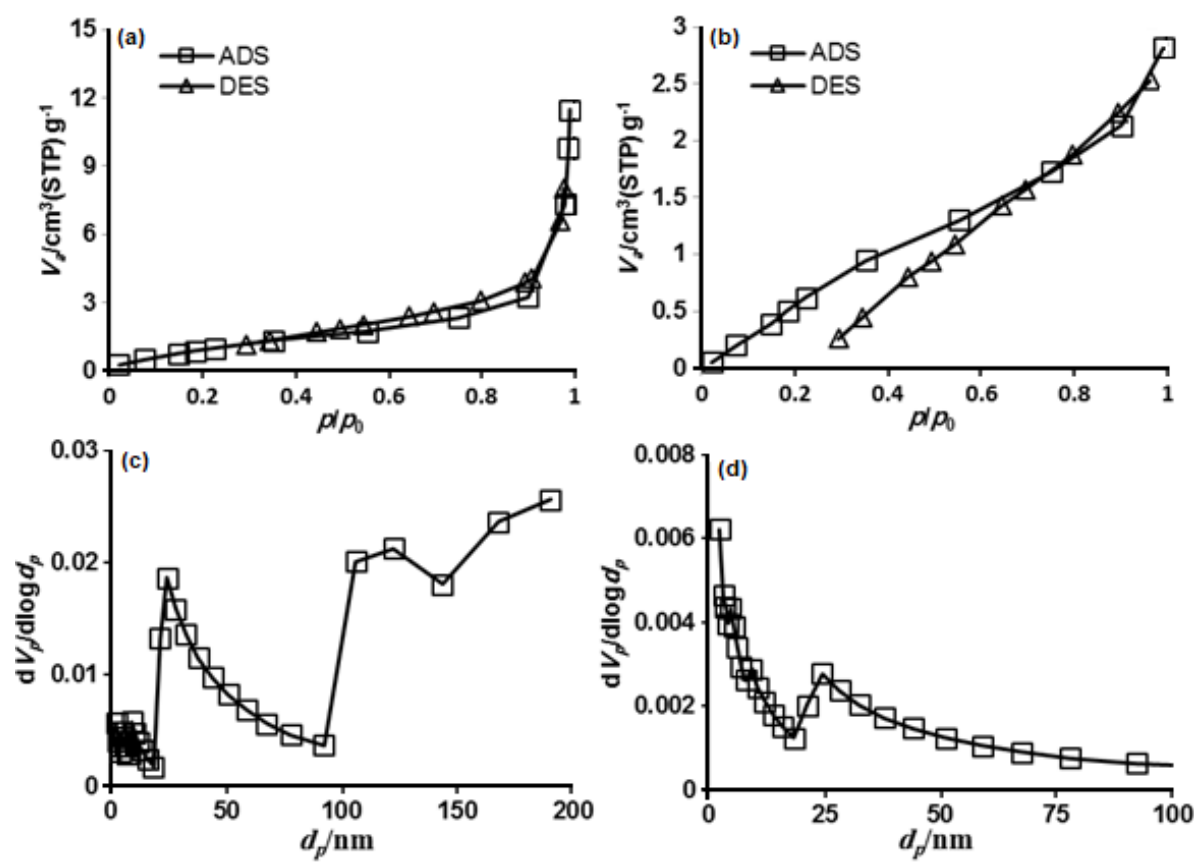

Fig 5. (a) and (b) BET isotherms of Nitrogen adsorption-desorption before and after dye adsorption respectively, (c) and (d) BJH pore size distribution curves before and after adsorption respectively 
Table 1. Surface area, pore size and average diameter of MFS and MFS-RB

\begin{tabular}{lccc}
\hline & $\begin{array}{c}\text { Surface } \\
\text { area }\left(\mathrm{m}^{2} / \mathrm{g}\right)\end{array}$ & $\begin{array}{c}\text { Pore volume } \\
(\mathrm{cc} / \mathrm{g})\end{array}$ & $\begin{array}{c}\text { Average pore } \\
\text { diameter }(\mathrm{nm})\end{array}$ \\
\hline MFS & 4.4 & 0.0177 & 190.55 \\
MFS-RB & - & 0.0050 & 2.43 \\
\hline
\end{tabular}

the classification proposed by (IUPAC), the isotherms of MFS can be classified as type III, where the adsorbate uptake increases exponentially due to the weak interaction between the adsorbate $\left(\mathrm{N}_{2}\right.$ gas) and the adsorbent and to the microporous nature [21]. In reference to literature, the hysteresis loops of MFS is $\mathrm{H} 3$ type which is indexed to the presence of non-rigid aggregates of sheet-like particles or assemblages of slitshaped pores [22]. The surface area of MFS was $4.4 \mathrm{~m}^{2} / \mathrm{g}$. whereas MFS after the adsorption of RB have schematically undefined curves and cannot be applied to the BET sorption isotherm models which may be due to

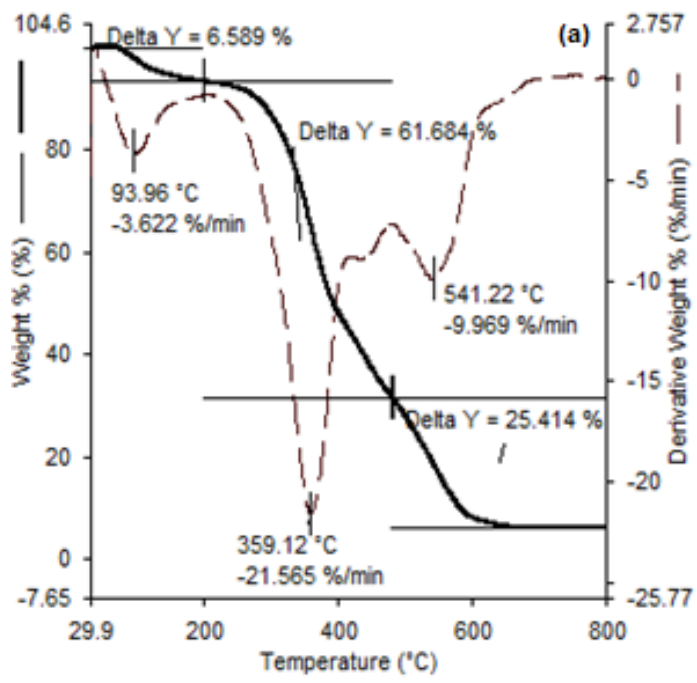

lower surface area of the sample. This results complies with their morphology (Fig. 3 and Fig. 4). The pore volume and pore diameter of the MFS surface decreased with the adsorption of molecules due to the filling of the pore voids with the dye molecules. Results show that the pore volume decreased by $71.29 \%$, and the average diameter decreased from 190.55 to $2.43 \mathrm{~nm}$ due to the dye adsorption on the MFS surface.

\section{Thermal Analysis}

The Thermogravimetric analysis results of MFS before and after dye adsorption are shown in Fig. 6. TGA and DTA curves of MFS show three steps in weight loss (Table 2); The first stage of weight loss in the temperature range of 30 to $200{ }^{\circ} \mathrm{C}$ represents the removal of physically adsorbed water [23]. The second step of weight loss in the temperature range of $200-500{ }^{\circ} \mathrm{C}$ can be attributed to the organic breakdown of MFS biomass and the loss of the organic volatile compounds. The third

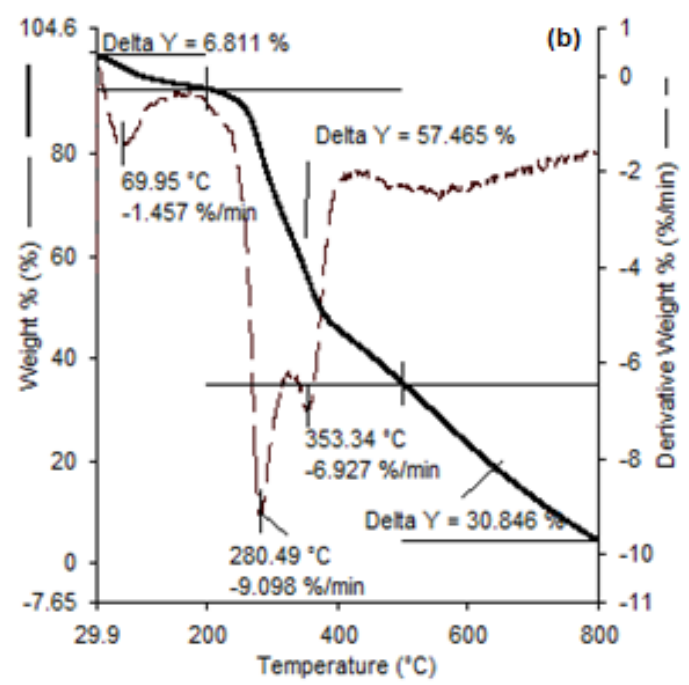

Fig 6. TGA/DTA curves of MFS (a) before and (b) after dye adsorption

Table 2. TGA/DTA data of MFS and MFS-RB before and after adsorption of RB

\begin{tabular}{lccccl}
\hline & $\begin{array}{c}\text { DTG peak } \\
\left({ }^{\circ} \mathrm{C}\right)\end{array}$ & $\begin{array}{c}\text { TG range } \\
\left({ }^{\circ} \mathrm{C}\right)\end{array}$ & $\begin{array}{c}\text { Mass loss } \\
(\%)\end{array}$ & $\begin{array}{c}\text { Remaining } \\
\text { mass }\end{array}$ & Possible explanation \\
\hline \multirow{3}{*}{ MFS } & 93.96 & $30-200$ & 6.589 & 93.411 & Dehydration \\
& 359.12 & $200-480$ & 61.684 & 31.727 & Volatilization of organic compounds \\
& 541.22 & $480-800$ & 25.414 & 6.313 & Carbonation \\
\hline \multirow{3}{*}{ MFS-RB } & 160.38 & $30-200$ & 6.811 & 93.189 & Dehydration \\
& 237.76 & $200-500$ & 57.465 & 35.724 & Volatilization of organic compounds \\
& - & $500-800$ & 30.846 & 4.878 & Carbonation and Volatilization of RB dye \\
\hline
\end{tabular}


stage occurred in the range of temperature of $500-800{ }^{\circ} \mathrm{C}$ which corresponds to the carbonization of the material and formation of charcoal [24]. The charcoal residues after MFS and MFS-RB were heated to $800{ }^{\circ} \mathrm{C}$, were 6.313 and $4.878 \%$, respectively. The decrease in the residues percentage (1.435\%) of MFS-RB was due to the pyrolysis of the RB dye in the third stage of the TGA analysis, in accordance to the data obtained from the lookchem supplier web, in which the RB dye boiling point is $741.8^{\circ} \mathrm{C}$ at $760 \mathrm{mmHg}$ [25].

\section{Effect of Contact Time and Adsorption Kinetics}

The time-dependent behavior of the dye adsorption was investigated by varying the contact time between the $\mathrm{RB}$ dye and the MFS in the range of 5-75 min. The concentrations of the dye was kept at $50 \mathrm{ppm}$ and MFS mass was kept at $1.7 \mathrm{~g}$. The result for the removal of $\mathrm{RB}$ versus contact time is presented in Fig. 7. More than $80 \%$ of dye was adsorbed at contact time of $10 \mathrm{~min}$ and adsorption increased with time reaching to a maximum value in $65 \mathrm{~min}$ and afterwards remained constant. In context, the adsorption equilibrium time of the RB dye was $65 \mathrm{~min}$ for MFS.
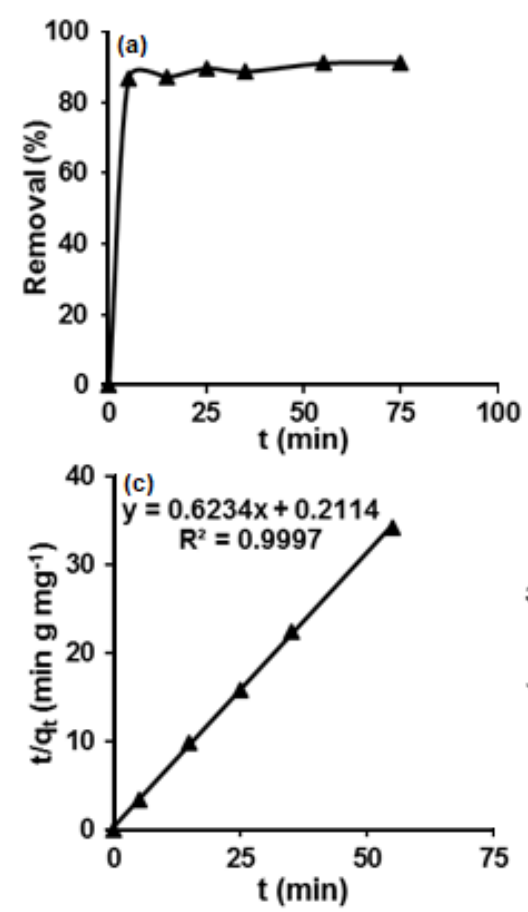

To investigate the kinetic mechanism of adsorption, the experimental data was fitted to the pseudo-first order, the pseudo-second order, and intraparticle diffusion models. The three models are generally expressed as follows:

Pseudo-first order model (linear form) [26]:

$\ln \left(\mathrm{q}_{\mathrm{e}}-\mathrm{q}_{\mathrm{t}}\right)=\ln \mathrm{q}_{\mathrm{e}}-\mathrm{k}_{1} \mathrm{t}$

Pseudo-second order model (linear form) [27]:

$\frac{\mathrm{t}}{\mathrm{q}_{\mathrm{t}}}=\frac{1}{\mathrm{k}_{2} \mathrm{q}_{\mathrm{e}}^{2}}+\frac{1}{\mathrm{q}_{\mathrm{e}}} \mathrm{t}$

Intraparticle diffusion model (linear form) [28]:

$\mathrm{q}_{\mathrm{t}}=\mathrm{k}_{\mathrm{p}} \mathrm{t}^{0.5}+\mathrm{I}$

where $\mathrm{q}_{\mathrm{e}}$ and $\mathrm{q}_{\mathrm{t}}=$ the amount of $\mathrm{RB}$ adsorbed at equilibrium and at $\mathrm{t}$ time, respectively $\left(\mathrm{mg} \cdot \mathrm{g}^{-1}\right), \mathrm{k}_{1}=$ the overall rate constant of pseudo-first order kinetics $\left(\mathrm{min}^{-1}\right.$ $\left.\mathrm{mg} \mathrm{g}^{-1}\right), \mathrm{k}_{2}=$ the rate constant of pseudo-second order $\left(\mathrm{mg} \mathrm{g}^{-1} \mathrm{~min}^{-1}\right), \mathrm{K}_{\mathrm{P}}=$ the rate constant of intraparticle diffusion $\left(\mathrm{mg} \mathrm{g}^{-1} \mathrm{~min}^{-1 / 2}\right)$ and $\mathrm{I}=$ the intercept reflecting the thickness of boundary layer.

Fig. 7(b), (c) and (d) show the kinetic models of RB adsorption on the MFS surface. The adsorption kinetic pseudo-second order was more linear with $\mathrm{R}^{2}$ of 0.999
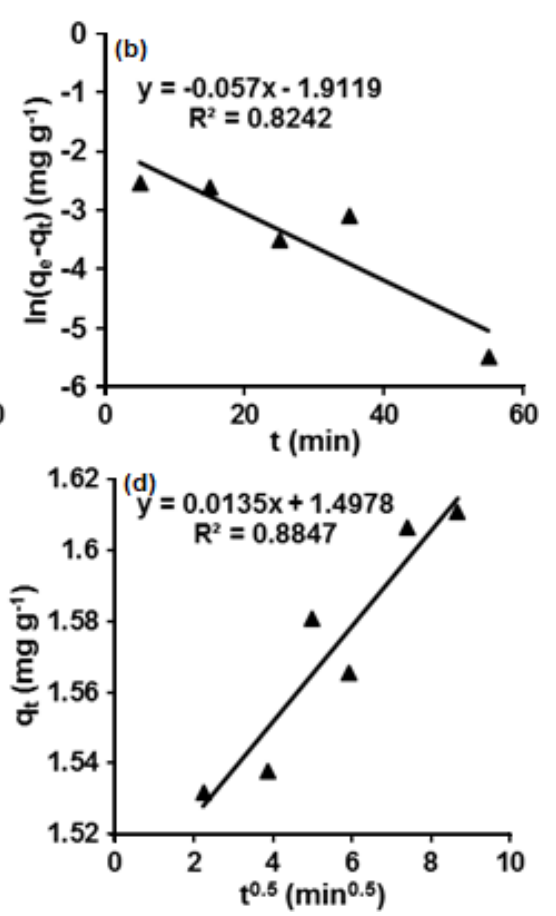

Fig 7. The removal and kinetics graphs models: (a) the removal (b) pseudo-first order (c) pseudo-second order and diffusion kinetics models of (d) intraparticle diffusion of RB using MFS 
Table 3. Kinetic data of adsorption RB onto MFS

\begin{tabular}{lccccccccc} 
& First order & \multicolumn{3}{c}{ Second order } & \multicolumn{5}{c}{ Intraparticle diffusion } \\
\hline $\begin{array}{l}\mathrm{qe}_{\text {exp }} \\
(\mathrm{mg} / \mathrm{g})\end{array}$ & $\begin{array}{c}\mathrm{k}_{1} \\
\left(\mathrm{~min}^{-1} \mathrm{mg} \mathrm{g}^{-1}\right)\end{array}$ & $\begin{array}{c}\mathrm{q}_{\text {e cal }} \\
(\mathrm{mg} / \mathrm{g})\end{array}$ & $\mathrm{R}^{2}$ & $\begin{array}{c}\mathrm{k}_{2}(\mathrm{~min} . \\
\mathrm{g} / \mathrm{mg})\end{array}$ & $\begin{array}{c}\mathrm{q}_{\text {e cal }} \\
(\mathrm{mg} / \mathrm{g})\end{array}$ & $\mathrm{R}^{2}$ & $\begin{array}{c}\mathrm{k}_{\mathrm{p}} \\
\left(\mathrm{mg} \mathrm{g}^{-1} \mathrm{~min}^{-1 / 2}\right)\end{array}$ & $\begin{array}{c}\mathrm{C} \\
(\mathrm{mg} / \mathrm{g})\end{array}$ & $\mathrm{R}^{2}$ \\
\hline 1.610 & 0.057 & 0.147 & 0.824 & 0.902 & 1.622 & 0.999 & 0.013 & 1.497 & 0.884 \\
\hline
\end{tabular}

compared to the pseudo-first order plot and intraparticle diffusion plot (see Table 3). In addition, the value of $\left(\mathrm{q}_{\mathrm{e}}\right.$ cal) in this model is closer and more accurate than the other models. This result confirmed that the adsorption process followed the pseudo-second order which assumed that chemisorption occurred, which involved chemical reactions between adsorbent and adsorbate [29].

\section{Adsorption Isotherm Studies}

Fig. 8(a) shows the adsorption isotherm of RB dye. Referring to the theoretical basis of Giles's classification of adsorption isotherms, the isotherm of RB was of S-type, which assumed that the adsorbent is possibly mesoporous or is not porous and has a high energy of adsorption. The reaction between adsorbent and adsorbate can be determined by isotherm study. There are different isotherm equations available for studying the experimental sorption equilibrium data. However, the most common types of isotherms are the Langmuir, Temkin and Freundlich models:

Langmuir isotherm model [30]:

$\frac{\mathrm{C}_{\mathrm{e}}}{\mathrm{q}_{\mathrm{e}}}=\frac{\mathrm{C}_{\mathrm{e}}}{\mathrm{q}_{\mathrm{m}}}+\frac{1}{\mathrm{~K}_{\mathrm{a}} \mathrm{q}_{\mathrm{m}}}$

Freundlich isotherm model [31]:

$\log \mathrm{q}_{\mathrm{e}}=\log \mathrm{K}_{\mathrm{f}}+\mathrm{l} / \mathrm{n}\left(\log \mathrm{C}_{\mathrm{e}}\right)$

Temkin isotherm model [32]:

$\mathrm{q}_{\mathrm{e}}=\mathrm{B}_{1} \ln \mathrm{K}_{\mathrm{T}}+\mathrm{B}_{1} \ln \mathrm{C}_{\mathrm{e}}$

where $\mathrm{q}_{\mathrm{e}}=$ the amount of $\mathrm{RB}$ adsorbed $(\mathrm{mg} / \mathrm{g})$ at $\mathrm{Ce}$ (equilibrium concentration), $\mathrm{q}_{\mathrm{m}}$ and $\mathrm{k}_{\mathrm{a}}$ are Langmuir constants related to adsorption efficiency and energy of adsorption, respectively. $K_{f}$ and $1 / n$ are constants incorporating the factors affecting the adsorption capacity and intensity of adsorption, respectively. $\beta=\mathrm{RT} / \mathrm{b},(\mathrm{T})$ is the thermodynamic temperature in Kelvin degrees and $(\mathrm{R})$ is the universal gas constant, $8.314 \mathrm{~J} \mathrm{~mol}^{-1} \mathrm{~K}^{-1}$. The constant (b) is identified as the adsorption heat.
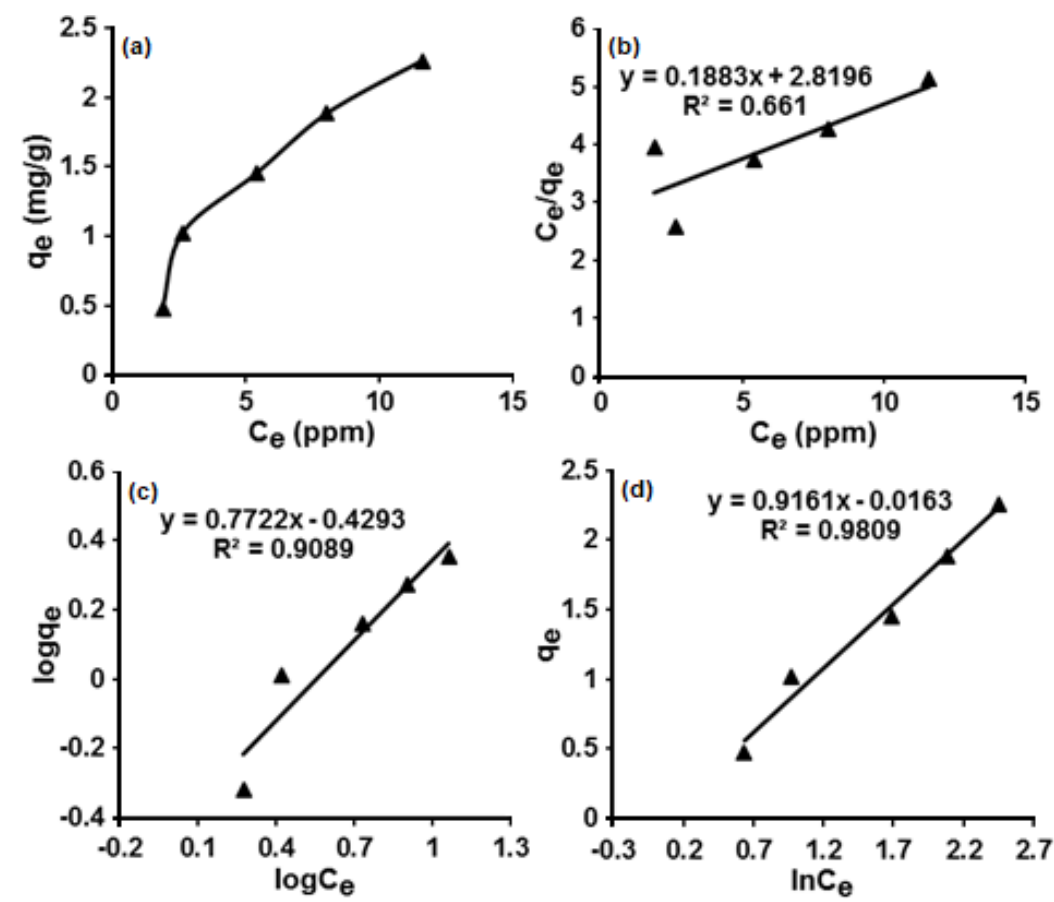

Fig 8. (a) Adsorption isotherm, (b) Langmuir model, (c) Freundlich model and, (d) Temkin model of dye at pH 7 and $25^{\circ} \mathrm{C}$ 
Table 4. Isotherm models data of adsorption RB onto MFS

\begin{tabular}{ccccccccc}
\hline \multicolumn{2}{c}{ Langmuir isotherm } & \multicolumn{2}{c}{ Freundlich isotherm } & \multicolumn{3}{c}{ Temkin isotherm } \\
\hline $\mathrm{K}_{\mathrm{a}}\left(\mathrm{L} \mathrm{mg}^{-1}\right)$ & $\mathrm{q}_{\mathrm{m}}(\mathrm{mg} / \mathrm{g})$ & $\mathrm{R}^{2}$ & $\mathrm{~K}_{\mathrm{F}}\left(\mathrm{mg} / \mathrm{g}(\mathrm{L} / \mathrm{mg})^{1 / \mathrm{n}}\right)$ & $\mathrm{n}$ & $\mathrm{R}^{2}$ & $\mathrm{~K}_{\mathrm{T}}\left(\mathrm{L} \mathrm{g}^{-1}\right)$ & $\mathrm{B}$ & $\mathrm{R}^{2}$ \\
\hline 0.066 & 5.310 & 0.661 & 0.372 & 1.295 & 0.908 & 0.982 & 0.916 & 0.980 \\
\hline
\end{tabular}

Fig. 8(b), (c) and (d) show the isotherm models of $\mathrm{RB}$ adsorption on the MFS surface. It is clearly seen that plot of Temkin isotherm is more linear with $R^{2}$ of 0.980 in comparison to other models of isotherms (show Table 4). Temkin isotherm contains a factor that explicitly taking into the account of adsorbent-adsorbate interactions and assumes that heat of adsorption of all molecules in the layer would decrease linearly rather than in logarithmic manner with the coverage [33].

\section{Adsorbent dosage}

To optimize the MFS dosage, the effect of adsorption amount on removal of RB dye was carried out. Fig. 9(a) shows the dependence of MFS mass on RB adsorption percentage. It was observed that RB removal increased with the increase of the amount of MFS adsorbent. The maximum removal of dyes was observed with the dosage $(1.7 \mathrm{~g})$ used for all subsequence experiments the results are shown in Fig. 9(a).

\section{Initial $\mathrm{pH}$ effect}

Different $\mathrm{pH}$ values $(3,4,9$ and 12) were used to study the $\mathrm{pH}$ effect on adsorption of RB dye onto MFS. Initial $\mathrm{pH}$ dye solutions were adjusted by using $0.1 \mathrm{~N}$ of $\mathrm{HCl}$ and $0.1 \mathrm{~N}$ of $\mathrm{NaOH}$. Fig. 9(b) depicts the relationship between $\mathrm{RB}$ removal percentages with the initial $\mathrm{pH}$ values of the $\mathrm{RB}$ solutions. It is clearly seen that the amount of dyes removed at $\mathrm{pH} 3$ produced a large adsorbate quantity. The dye removal was expected to increase due to the esterification process that was found to be more favorable at acidic solution $(\mathrm{pH}<3)$. The IR spectral lines proves the occurrence of esterification by the appearance of a peak at $1734 \mathrm{~cm}^{-1}$.

\section{Effect of Temperature}

The effect of temperature on $\mathrm{RB}$ adsorption on MFS surface at $(35-55){ }^{\circ} \mathrm{C}$ is shown in Fig. 10(a). It shows that the adsorption process decreased with the rise in temperature due to the reduced attractive forces between the RB molecules and MFS [34]. The enthalpy variation $(\Delta \mathrm{H})$, and other thermodynamic parameters such as free energy variation $(\Delta G)$, and entropy variation $(\Delta S)$ follows the following equations [35]:

$\ln \mathrm{X}_{\mathrm{m}}=\frac{-\Delta \mathrm{H}}{\mathrm{RT}}+\mathrm{C}$

$\Delta \mathrm{G}=-\mathrm{RT} \ln \mathrm{K}$

$\Delta \mathrm{G}=\Delta \mathrm{H}-\mathrm{T} \Delta \mathrm{S}$

where $\mathrm{X}_{\mathrm{m}}$ is the maximum amount adsorbed $\left(\mathrm{q}_{\mathrm{m}}\right)$ at a certain value of concentration equilibrium $\left(\mathrm{C}_{\mathrm{e}}\right)$, and $(\mathrm{K})$ is the distribution coefficient. The value of $\Delta \mathrm{H}^{\circ}$ was determined from the slope value of the straight line of plotting $\ln \mathrm{X}_{\mathrm{m}}$ versus $1 / \mathrm{T}$ (Fig. 10(b)). The negative value of enthalpy $(\Delta \mathrm{H}=-42.447 \mathrm{~kJ} / \mathrm{mol})$ and entropy $(\Delta \mathrm{S}=$ $\left.147 \mathrm{~J} \mathrm{~mol}^{-1} \mathrm{~K}^{-1}\right)$, confirmed the exothermic process and that the RB molecules have ordered arrangement on MFS surface [36]. On the other hand, the positive value of free energy $(\Delta \mathrm{G}=+3065 \mathrm{~kJ} / \mathrm{mol})$ indicated that the adsorption
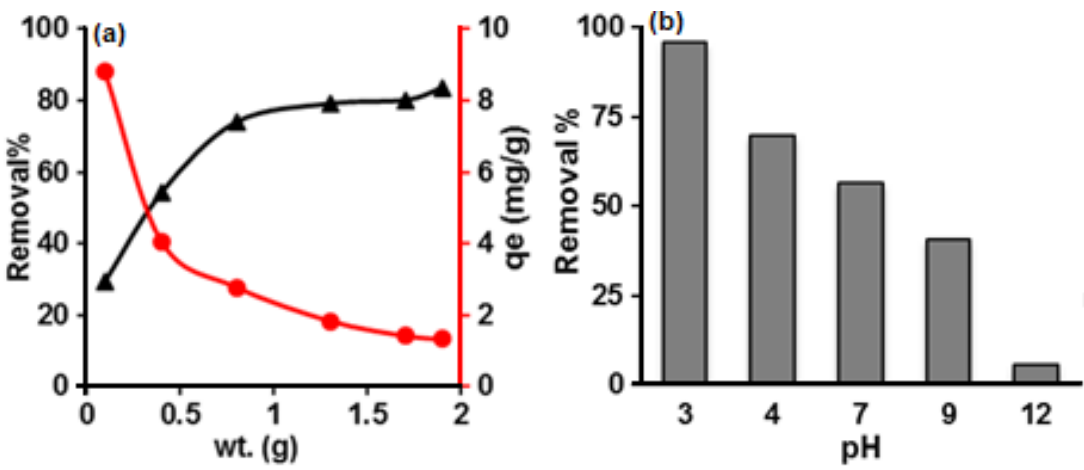

Fig 9. (a) Effect of adsorbent dosage and, (b) pH effect on adsorption of RB 

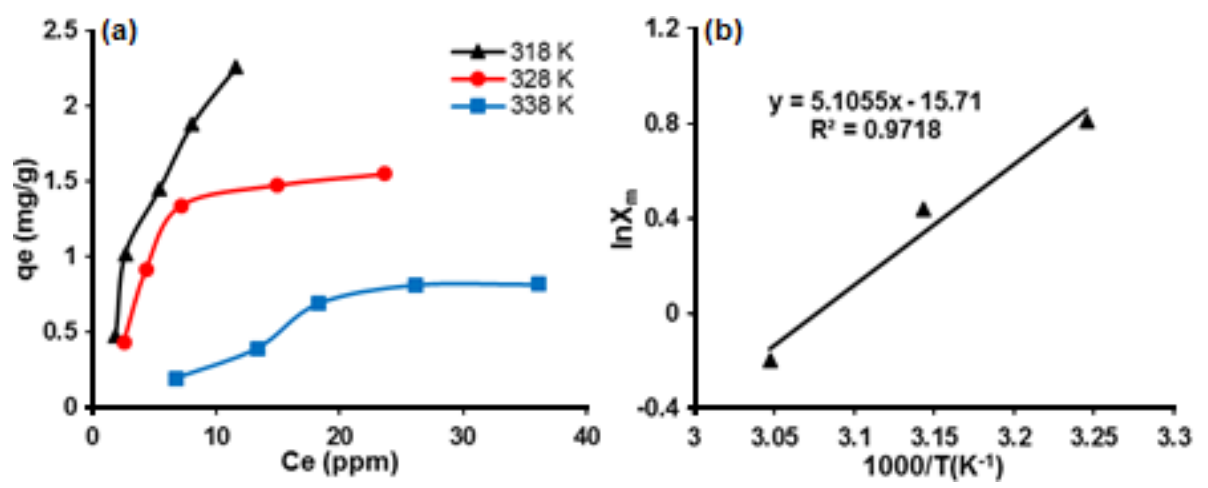

Fig 10. (a) Effect of temperature and, (b) Van't Hoff plots for the adsorption of RB onto MFS surface

process was thermodynamically non-spontaneous [35]. The value of $\Delta \mathrm{H}$ was more than $40 \mathrm{~kJ} / \mathrm{mol}$ which indicates that the uptake of RB dye onto MFS could be attributed to a chemisorption process [37].

\section{CONCLUSION}

In the present study, we examined the adsorption of Rose Bengal onto Myristica fragrans shells. We strongly suggest that chemisorption by ester bond formation between adsorbate and adsorbent occurred. This result was confirmed by FTIR and adsorption study.

\section{- REFERENCES}

[1] Tang, S.K., Teng, T.T., Alkarkhi, A.F.M., and Li, Z., 2012, Sonocatalytic degradation of Rhodamine B in aqueous solution in the presence of $\mathrm{TiO}_{2}$ coated activated carbon, APCBEE Procedia, 1, 110-115.

[2] Alwan, S.H., Alshamsi, H.A.H., and Jasim, L.S., 2018, Rhodamine B removal on A-rGO/cobalt oxide nanoparticles composite by adsorption from contaminated water, J. Mol. Struct., 1161, 356-365.

[3] Busquets, R., Kozynchenko, O.P., Whitby, R.L.D., Tennison, S.R., and Cundy, A.B., 2014, Phenolic carbon tailored for the removal of polar organic contaminants from water: A solution to the metaldehyde problem?, Water Res., 61, 46-56.

[4] Soliman, E.M., Ahmed, S.A., and Fadl, A.A., 2011, Reactivity of sugar cane bagasse as a natural solid phase extractor for selective removal of $\mathrm{Fe}(\mathrm{III})$ and heavy-metal ions from natural water samples, Arabian J. Chem., 4 (1), 63-70.

[5] Sorensen, J.P.R., Lapworth, D.J., Nkhuwa, D.C.W.,
Stuart, M.E., Gooddy, D.C., Bell, R.A., Chirwa, M., Kabika, J., Liemisa, M., Chibesa, M., and Pedley, S., 2015, Emerging contaminants in urban groundwater sources in Africa, Water Res., 72, 51-63.

[6] Jayanthy, V., Geetha, R., Rajendran, R., Prabhavathi, P., Sundaram, S.K., Kumar, S.D., and Santhanam, P., 2014, Phytoremediation of dye contaminated soil by Leucaena leucocephala (subabul) seed and growth assessment of Vigna radiata in the remediated soil, Saudi J. Biol. Sci., 21 (4), 324-333.

[7] Saggioro, E.M., Oliveira, A.S., Pavesi, T., Maia, C.G., Ferreira, L.F.V., and Moreira, J.C., 2011, Use of titanium dioxide photocatalysis on the remediation of model textile wastewaters containing azo dyes, Molecules, 16 (12), 10370-10386.

[8] Tabery, H.M., 1998, Toxic effect of Rose Bengal dye on the living human corneal epithelium, Acta Ophthalmol. Scand., 76 (2), 142-145.

[9] Vinuth, M., Naik, H.S.B., Vinoda, B.M., Pradeepa, S.M., Kumar, G.A., and Sekhar, K.S., 2016, Rapid removal of hazardous Rose Bengal dye using Fe(III) - Montmorillonite as an effective adsorbent in aqueous solution, J. Environ. Anal. Toxicol., 6 (2), 1000355.

[10] De Gisi, S., Lofrano, G., Grassi, M., and Notarnicola, M., 2016, Characteristics and adsorption capacities of low-cost sorbents for wastewater treatment: A review, Sustainable Mater.Technol., 9, 10-40.

[11] Kaur, J., and Singhal, S., 2014, Heterogeneous photocatalytic degradation of Rose Bengal: Effect of operational parameters, Physica B, 450, 49-53. 
[12] Bhaumik, R., Mondal, N.K., Das, B., Roy, P., Pal, K.C., Das, C., Baneerjee, A., and Datta, J.K., 2012, Eggshell powder as an adsorbent for removal of fluoride from aqueous solution: Equilibrium, kinetic and thermodynamic studies, E-J. Chem., 9 (3) 1457-1480.

[13] Alshamsi, H.A.H., and Alwan, S.H., 2015, Adsorptive removal of $\mathrm{Cd}$ (II) from aqueous solution onto beans peel powder as low cost adsorbent, Res. J. Pharm. Biol. Chem. Sci., 6 (6), 985-996.

[14] Bouamra, F., Drouiche, N., Abdi, N., Grib, H., Mameri, N., and Lounici, H., 2018, Removal of phosphate from wastewater by adsorption on marble waste: Effect of process parameters and kinetic modeling, Int. J. Environ. Res., 12, 13-27.

[15] Abdel-Salam, O.E., Reiad, N.A., and ElShafei, M.M., 2011, A study of the removal characteristics of heavy metals from wastewater by low-cost adsorbents, $J$. Adv. Res., 2 (4), 297-303.

[16] Syahiddin, D.S., and Muslim, A., 2018, Adsorption of $\mathrm{Cu}(\mathrm{II})$ ions onto Myristica fragrans shell-based activated carbon: Isotherm, kinetic and thermo dynamic studies, J. Korean Chem. Soc., 62 (2), 79-86.

[17] Uppal, A., Jain, B., Gupta, P.K., and Das, K., 2011, Photodynamic action of Rose Bengal silica nanoparticle complex on breast and oral cancer cell lines, Photochem. Photobiol., 87 (5), 1146-1151.

[18] Bodîrlău, R., and Teacă, C.A., 2009, Fourier transform infrared spectroscopy and thermal analysis of lignocellulose fillers treated with organic anhydrides, Rom. J. Phys., 54 (1-2), 93-104.

[19] Kumar, B.R., and Rao, T.S., 2012, AFM studies on surface morphology, topography and texture of nanostructured zinc aluminum oxide thin films, Dig. J. Nanomater. Bios., 7 (4), 1881-1889.

[20] Altaa, S.H.A., Alshamsi, H.A.H., and Al-Hayder, L.S.J., 2018, Synthesis and characterization of $\mathrm{rGO} / \mathrm{Co}_{3} \mathrm{O}_{4}$ composite as nanoadsorbent for Rhodamine 6G-dye removal, Desalin. Water Treat., 114, 320-331.

[21] Kshirsagar, A.S., and Khanna, P.K., 2019, $\mathrm{CuSbSe}_{2} / \mathrm{TiO}_{2}$ : Novel type-II heterojunction nanophotocatalyst, Mater. Chem. Front., 3 (3), 437-449.
[22] Al-Taweel, S.S., Saud, H. R., Kadhum, A.A.H., and Takriff, M.S., 2019, The influence of titanium dioxide nanofiller ratio on morphology and surface properties of $\mathrm{TiO}_{2} /$ chitosan nanocomposite, Results Phys., 13, 102296.

[23] Ali, A.S., Mohammed, A.J., and Saud, H.R., 2018, Hydrothermal synthesis of $\mathrm{TiO}_{2} / \mathrm{Al}_{2} \mathrm{O}_{3}$ nanocomposite and its application as improved sonocatalyst, Int. J. Eng. Technol., 7 (4), 22-25.

[24] Cao, J., Xiao, G., Xu, X., Shen, D., and Jin, B., 2013, Study on carbonization of lignin by TG-FTIR and high-temperature carbonization reactor, Fuel Process. Technol., 106, 41-47.

[25] lookchem, 2019, Rose Bengal lactone, https://www.lookchem.com/Rose-Bengal-lactone/.

[26] Lagergren, S., 1898, Zur theorie der sogenannten adsorption gelöster stoffe, Kungl. Sven. Vetenskapsakad. Handl., 24, 1-39.

[27] Ho, Y.S., and McKay, G., 1999, Pseudo-second order model for sorption processes, Process Biochem., 34 (5), 451-465.

[28] Kushwaha, J.P., Srivastava, V.C., and Mall, I.D., 2010, Treatment of dairy wastewater by commercial activated carbon and bagasse fly ash: Parametric, kinetic and equilibrium modelling, disposal studies, Bioresour. Technol., 101 (10), 3474-3483.

[29] Rahman, M.S., and Sathasivam, K.V., 2015, Heavy metal adsorption onto Kappaphycus sp. from aqueous solutions: The use of error functions for validation of isotherm and kinetics models, BioMed. Res. Int., 2015, 126298.

[30] Langmuir, I., 1918, The adsorption of gases on plane surfaces of glass, mica and platinum, J. Am. Chem. Soc., 40 (9), 1361-1403.

[31] Freundlich, H.M.F., 1906, Over the adsorption in solution, J. Phys. Chem., 57, 385-470.

[32] Tempkin, M.J., and Pyzhev, V., 1940, Recent modification to Langmuir isotherms, Acta Physiochem. USSR, 12, 217-222.

[33] Nechifor, G., Pascu, D.E., Pascu, M., Traistaru, G.A., and Albu, P.C., 2015, Comparative study of Temkin and Flory-Huggins isotherms for 
adsorption of phosphate anion on membranes, U.P.B. Sci. Bull., Ser. B, 77 (2), 63-72.

[34] Umoren, S.A., Etim, U.J., and Israel, A.U., 2013, Adsorption of methylene blue from industrial effluent using poly (vinyl alcohol), J. Mater. Environ. Sci., 4(1), 75-86.

[35] Al-Taweel, S.S., 2015, Equilibrium isotherm and kinetic studies of adsorption of basic Green-4 on titanium dioxide nanoparticles, Int. J. ChemTech Res., 8 (10), 116-125.
[36] Sharifipour, F., Hojati, S., Landi, A., and Faz Cano, A., 2015, Kinetics and thermodynamics of lead adsorption from aqueous solutions onto Iranian sepiolite and zeolite, Int. J. Environ. Res., 9 (3), 1001-1010.

[37] Adelodun, A.A., Ngila, J.C., Kim, D.G., and Jo, Y.M., 2016, Isotherm, thermodynamic and kinetic studies of selective $\mathrm{CO}_{2}$ adsorption on chemically modified carbon surfaces, Aerosol Air Qual. Res., $16,3312-3329$. 